Journal of Teacher Education for Sustainability, vol. 11, no. 2, pp. 41-50, 2009

\title{
STUDENTS MOTIVES AND SATISFACTION WITH STUDIES IN THE AREA OF NATURAL SCIENCES AND THEIR WILLINGNESS TO CONTINUE STUDIES IN TEACHER EDUCATION
}

\author{
Katrin Poom-Valickis and Tiina Elvisto \\ Tallinn University, Estonia
}

\begin{abstract}
Natural sciences teachers have a key role to play in creating knowledge and skills. However, Estonian students' interest in studying natural sciences and their willingness to continue studies in teacher education have decreased. This study was designed to assess: 1) how clear the students' motives to study natural sciences was; 2) how the clarity of motives relate to student satisfaction with their studies and 3) how student satisfaction with studies relate to their interest in continuing studies in teacher education. The participants of the study $(\mathrm{N}=92)$ were natural sciences students at Tallinn University. The data was collected using an adapted Learning and Studying Questionnaire by Entwistle et al. (2002) and questions designed by the authors of the study. The SPSS programme was used to analyse the data. The results of the study show that carefully planned curriculum selection and positive learning experiences increase student willingness to choose teacher education.
\end{abstract}

Key words: education for sustainable development; teacher education; natural science area; student motives; student satisfaction.

\section{Introduction}

Education is an essential tool for achieving sustainability. People around the world recognize that current economic development trends are not sustainable and that public awareness, education and training are the key to moving society toward sustainability. But at the same time people argue about the meaning of sustainable development and whether or not it is attainable. They have different visions of what sustainable societies will look like and how they will function. Of course, many truly great concepts of the human world - among them democracy and justice - are hard to define and have multiple expressions in cultures around the world.

In our opinion, education for sustainable development (ESD) is the use of education as a tool to achieve sustainability. Education is critical for achieving environmental and ethical awareness, values and attitudes as well as behaviours that are consistent with sustainable development and for effective public participation in decision-making. ESD has to be seen as a process of learning how to make decisions that consider the long- 
term future of the economy, ecology and equity of all communities. This vision of education emphasises a holistic, interdisciplinary approach to developing the knowledge and skills needed for a sustainable future as well as changes in values, behaviours and lifestyles (UNESCO, 2003).

The relationship between education and sustainable development is complex. Research shows that basic education is a key to a nation's ability to develop and achieve sustainability targets. The teacher and her/his competence have an essential effect on the quality of basic education. Thus, ESD poses new challenges for teachers and teacher education. ESD requires teachers engage pupils in a culture of argument, complexity, uncertainty and risk analysis. If teachers are to deliver ESD effectively, they need the right skills and tools. However, there are concerns that initial teacher training and continuing professional development do little to equip teachers with the skills and knowledge necessary to teach ESD in the cross-curricular manner (Learning the Sustainability Lesson, Environmental Audit Committee, 2003).

Another important issue is that in many countries there is a lack of young teachers. Fewer and fewer students are interested in continuing their educational career in teacher education. In recent years Tallinn University, one of the biggest universities in Estonia providing teacher education, has had difficulty enrolling even some state funded study places of subject teacher curricula. Furthermore, among those completing the teacher education programme, many do not enter the teaching profession. At the same time, the teaching staff is becoming increasingly senior in age (Riigikontrolli aruanne, 2004).

This article focuses on natural science teachers because they have an important role in producing competent environmental decision-makers. Sterling (2001) argues that the linear idea that more environmental education would change people and, therefore, society is simplistic and limited. Instead, all education, whether or not intended as such, should be treated as environmental. Nevertheless, subjects related to natural science are important parts of the school curriculum as they promote diverse forms of inquiry in the environment and encourage debate and decision-making on environmental issues. In the face of the challenges involving a lack of natural science teachers in schools, insufficient "offspring" and the fact that $12-18 \%$ of the teachers currently practising in the area do not meet the required qualification (data from Estonian Education and Information System), we analyse what influences and motivates students to enter and pursue the natural science curriculum and continue in teacher education.

\section{The study}

Estonian subject area teachers follow a $3+2$ programme in which the first three years are devoted to studies in the subject area chosen. After these studies, students may enter a programme at the MA level. They may choose either to continue subject matter studies or go into teacher education. Class teachers, in turn, study according to an integrated programme, meaning that they begin pedagogical studies right from the start of their education. It is worthwhile to mention here that based on the Rots et al. (2007) study, the non-integrated academic teacher education, i.e. the road which our future subject teachers follow too, is a negative predictor of graduates' entrance into the teaching profession. The integrated model appears to foster stronger commitment to teaching than the $3+2$ model, in which potential teacher candidates may be "lost" during the time of intensive subject matter study without pedagogical studies. 


\section{Method and sample}

This study was designed to assess: 1) how clear are the students' motives to study the area of natural sciences; 2 ) how clarity of motives relates to student satisfaction with their studies; 3 ) how student satisfaction with studies relates to their interest to continue studies in teacher education and 4) the reasons to choose or not to choose teacher education.

The data was collected using an adapted Learning and Studying Questionnaire by Entwistle et al. (2002) where 40 questions (using a five-point scale from agree to disagree) were divided into the following blocks: organisation and structure of curriculum, teaching and learning, students and teachers and assessment and individual work. Other questions were designed by the authors of the study considering the following topics: general satisfaction with studies, clarity of reasons and motives in choosing the university and the particular curriculum, reasons to continue studies at university, and probability of continuing studies under the teacher education curriculum after completion of the Bachelor's degree studies. All these were scaled questions. The last question in the questionnaire was an open-ended question to discover the possible reasons for choosing or not choosing the teaching profession.

\section{Data analysis}

The quantitative data was analysed using the SPSS programme. Descriptive statistics, group statistics, independent sample t-test as well correlation analyses were used. For reliability, internal consistency (Chronbach alpha) analyses were also conducted. The alpha was between $.72-.86$, which shows satisfactory internal reliability.

For analysis of qualitative data, both deductive category and inductive category development were used. Comparative coding among two coders was used for reliability. The coincidence/agreement rate of two investigations was $87 \%$ for the first and $83 \%$ for the second open question.

\section{Participants}

The participants of the study ( $\mathrm{N}=92$ ) were Bachelor level students of natural sciences at Tallinn University. Of them, 31 majored in biology 55 majored in geo-ecology and 6 majored in physics. After completion of the curriculum and obtaining their Bachelor's degree, the graduates can continue teacher education at the Master's degree level.

\section{The results}

To the question how clear their reasons and motives for starting studies under this particular curriculum in the area of natural sciences, $77 \%$ of the students answered that their reasons and motives were clear. However, for almost a quarter $(23 \%)$ of the students, the reasons and motives were not clear. This means that they chose the curriculum at random or were influenced by external factors. To get a better understanding of why the students chose to enter the particular university and curriculum, the students responded to a five-point scale about the importance of various factors that had affected their decision. The division of the students' assessment is presented in Figure 1. 


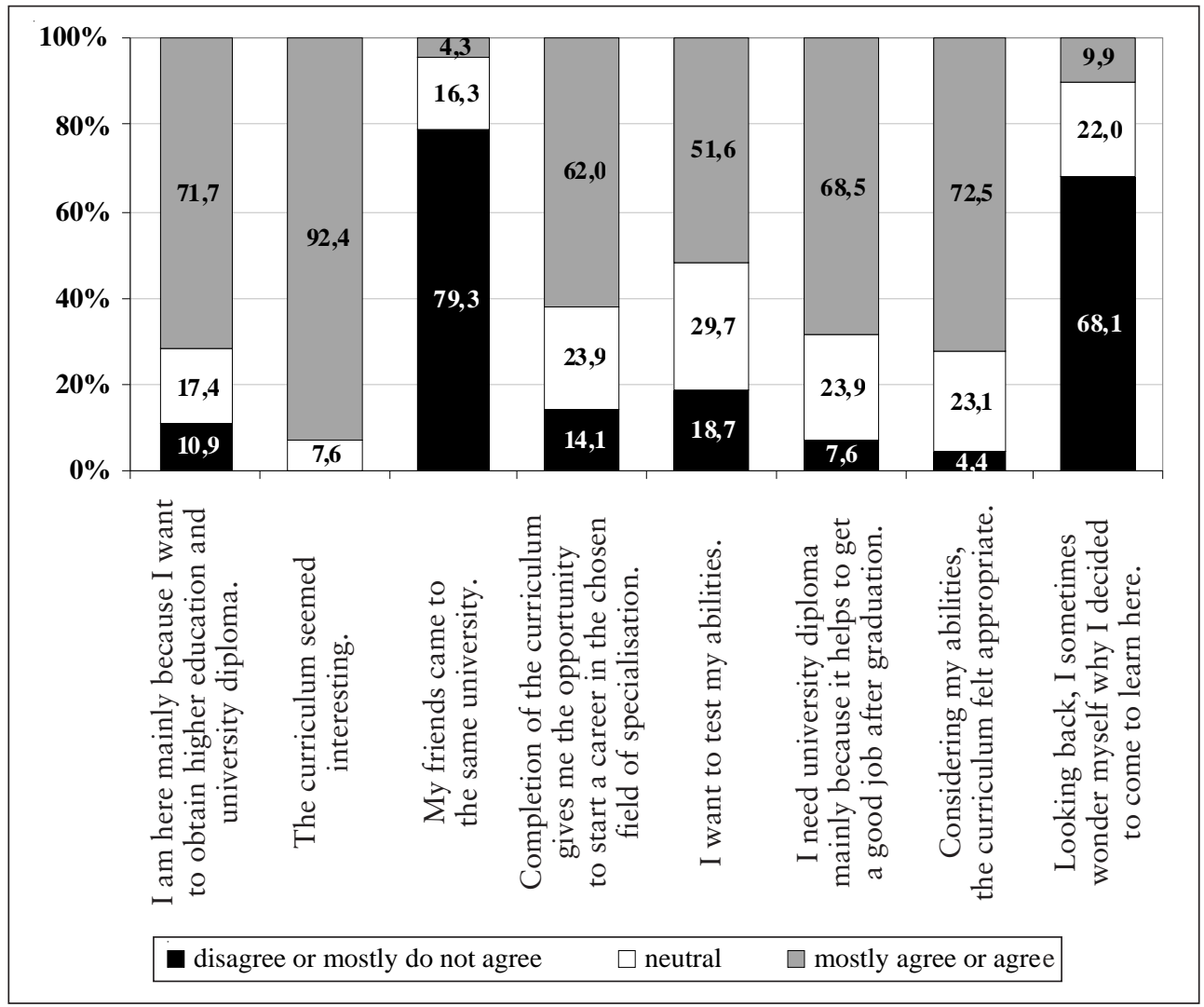

Figure 1. Students' assessment of the factors that affected their decision to choose the particular curriculum

The key factors that influenced students to continue their studies in the university were the following: (1) the curriculum seemed interesting $(92 \%) ;(2)$ the curriculum seemed suitable to their abilities $(73 \%)$; (3) the main reason for studying was to obtain a higher education and a university diploma (72\%).

The influence of friends in the selection process was insignificant as only $4 \%$ of the respondents agreed that their choice was affected by friends who came to study in the same university. Other researchers have also found that there are very few students who feel that they were influenced by their friends' decisions (Byrne \& Flood, 2005). Yet $10 \%$ of the participants admit that looking back they sometimes wonder why they had decided to enter the specific field of studies in the first place. While the motives for $23 \%$ of the students and reasons for choosing the curriculum were not clear, $10 \%$ continued to have doubts about their choice.

The second research question was: "How does the clarity of motives relate to students' satisfaction with their studies?" As mentioned above, to assess student satisfaction with their studies, we adapted the Learning and Studying Questionnaire by Entwistle et al. (2002), where the questions were divided into the following blocks: organisation and structure of curriculum, teaching and learning, students and teachers, and assessment and individual work. The authors of the study added a fifth block 
measuring the students' overall satisfaction with statements such as: "I am satisfied with my learning experiences at the university; I am satisfied with my intellectual development across studies."

To find out whether the clarity of motives relates to students' satisfaction with their studies, the average evaluations of two groups of students (a) students whose motives and reasons for selecting the curriculum were clear and (b) students whose motives and reasons for selecting the curriculum were vague were compared by using a t-test. Statistically significant differences were manifest in three of the five blocks (Table 1). Namely statistically significant differences appeared in the blocks: organisation and structure of the curriculum $(\mathrm{p}<.01)$, teaching and learning $(\mathrm{p}<.05)$, and general satisfaction with studies $(\mathrm{p}<.01)$. This indicates that the more informed and considered the choice of curriculum is, the greater the student's satisfaction with studies is.

Table 1. Average evaluations of students' satisfaction with their studies based on the clarity of motives and reasons for starting studies under this particular curriculum

\begin{tabular}{|c|c|c|c|c|c|}
\hline \multirow{2}{*}{\multicolumn{2}{|c|}{$\begin{array}{l}\text { Study experience } \\
\text { at the university }\end{array}$}} & \multicolumn{2}{|c|}{$\begin{array}{l}\text { Clarirty of reasons and } \\
\text { motives for starting } \\
\text { studies under this } \\
\text { particular curriculum }\end{array}$} & \multirow[t]{2}{*}{$\mathrm{p}$} & \multirow[t]{2}{*}{$\begin{array}{l}\text { Group } \\
\text { Total }\end{array}$} \\
\hline & & Vague & Clear & & \\
\hline \multirow{3}{*}{$\begin{array}{l}\text { Organisation and } \\
\text { structure }\end{array}$} & Mean & 3,13 & 3,67 & \multirow[t]{3}{*}{,001 } & 3,55 \\
\hline & Std Deviation &, 69 & ,64 & &, 69 \\
\hline & Valid N & 21 & 71 & & 92 \\
\hline \multirow{3}{*}{$\begin{array}{l}\text { Teaching and } \\
\text { learning }\end{array}$} & Mean & 3,51 & 3,88 & \multirow[t]{3}{*}{,003 } & 3,79 \\
\hline & Std Deviation &, 40 &, 50 & &, 50 \\
\hline & Valid N & 21 & 71 & & 92 \\
\hline \multirow{3}{*}{$\begin{array}{l}\text { Students and } \\
\text { teachers }\end{array}$} & Mean & 3,71 & 3,84 & \multirow[t]{3}{*}{,335 } & 3,81 \\
\hline & Std Deviation &, 49 &, 53 & &, 52 \\
\hline & Valid N & 21 & 71 & & 92 \\
\hline \multirow{3}{*}{$\begin{array}{l}\text { Assessment and } \\
\text { individual work }\end{array}$} & Mean & 3,94 & 4,05 & \multirow[t]{3}{*}{,384 } & 4,02 \\
\hline & Std Deviation &, 48 & ,48 & & ,48 \\
\hline & Valid N & 21 & 71 & & 92 \\
\hline \multirow{3}{*}{$\begin{array}{l}\text { General } \\
\text { satisfaction }\end{array}$} & Mean & 3,75 & 4,29 & \multirow[t]{3}{*}{,014 } & 4,16 \\
\hline & Std Deviation &, 88 &, 59 & &, 70 \\
\hline & Valid N & 21 & 71 & & 92 \\
\hline
\end{tabular}

One of the objectives of this study was to find out what affected student choices and willingness to continue or discontinue their studies in teacher education. Therefore, the students were first asked to answer the question "How do you evaluate the probability of continuing studies under the teacher education curriculum after completion of the Bachelor's degree studies?" The responses were not very positive. Only 33 students $(36 \%)$ said that it was likely or very likely that they would continue in teacher education. 59 students $(64 \%)$ were of the opinion that teacher education would not be their first choice after obtaining the Bachelor's degree. 
A statistically significant difference became apparent $(\mathrm{p}<.05)$ upon analysing whether there were any correlative relationships between the students' awareness of choosing the curriculum and interest in continuing studies in teacher education. It appeared that the more informed the choice of curriculum on the Bachelor's degree level, the greater the probability that the student continued in teacher education. It is possible that many of the students had thought about teacher education, i.e. had the desire of becoming a teacher of the subject area already upon entering the university.

However, there were no significant differences between students' satisfaction with their studies and interest in continuing studies in teacher education. This indicates that the most important factor is an informed choice of curriculum, which affects both satisfaction with studies and the desire to continue in teacher education. However, a positive learning experience obtained in the university does not affect students' desire to continue in teacher education.

To ascertain the causes that affect students' choice of curriculum and the teacher's profession, two open questions were included where the students were asked to substantiate why they wanted or did not want to be involved in teaching in the future. The first open question was analysed applying a deductive approach, where categories were formed on the basis of Kyriacou and Coulthard's (2000) categories. Namely, several earlier findings have shown (Kyriacou \& Coulthard, 2000) that the main reasons for choosing teaching as a career fall into three main areas: (1) altruistic reasons: these reasons deal with seeing teaching as a socially worthwhile and important job, a desire to help children succeed, and desire to help society improve; (2) intrinsic reasons: these reasons cover aspects of the job activity itself, such as the activity of teaching children, and an interest in using their subject matter knowledge and expertise and (3) extrinsic reasons. The extrinsic reasons cover aspects of the job which are not inherent in the work itself, such as long holidays, level of pay and status.

The reasons of choosing teaching as a career for the students who participated in the study were divided into three categories as follows:

(1) Altruistic reasons were mentioned 9 times.

"The opportunity to make a positive difference in the educational system, to guide students, to shape their values and thus improve the world".

(2) Intrinsic reasons were mentioned 31 times.

"I have always wanted to be a teacher. I love being involved with children and passing my knowledge to them. I think I am good at explaining my subject”.

(3) Extrinsic reasons were mentioned 13 times.

"Teachers have steady state employment and salary and there is always a need for young teachers".

Thus, the biggest number of students made their career choice due to intrinsic reasons, which confirms the researchers' presumption that a large number of students who wish to continue studies in teacher education after obtaining their Bachelor's degree have made their choice already by the time they choose the curriculum. This is further established by a relationship that appeared on statistical data analysis that the more 
informed the choice of curriculum is, the greater the probability that the student continues studies in teacher education.

Ascertaining the factors and reasons why students do not choose teacher education is just as important as finding out the reasons why students have made such choice. The relevant open question was analysed by applying an inductive approach and as the result four categories emerged:

(1) causes that are related to the respondent, i.e. absence of necessary personal qualities;

(2) causes that are related to work, i.e. profession-related deficiencies, including both material and learner-related issues;

(3) there are better opportunities for self-realization, including other interests which do not include teaching;

(4) students who have not made up their minds yet, i.e. not made their final choice.

The responses fell into the categories as follows. Work-related deficiencies were mentioned most frequently (incl. both material reasons and student-related reasons) 36 times. For example: "In my opinion, the workload and the level of commitment are not in conformity with the salary, especially in the case of young teachers" or "The job causes stress". "You have to carry work home." "Some students are undisciplined," etc.

Absence of personal qualities necessary for work as teacher ranked second, mentioned 23 times. For example: "I do not think that I have all the qualities that are necessary to become a good teacher" or "I am too modest." "A good teacher must have the talent of passing her knowledge successfully and in a fascinating manner." "I think I do not have the talent."

The opinion that there are better professions and opportunities for self-realization than teaching ranked third, mentioned 15 times. For example: "I think there are many other better jobs to realize myself."

Responses of five students were classified under the fourth category, i.e. they had not made their final choice yet. For example: "I did not come to the university to become a teacher, but the challenge whether I can cope as teacher has been on my mind, indeed."

We can argue that the most essential reason why students choose not to take up teacher education and teaching as career relates to the level of difficulty of the career and related problems. Students mention both economic and student-related problems. On the other hand, students' belief that teachers' salary is low is not quite true and management of pupils who have learning or behavioural problems depends largely on the teacher and the internal cooperation within the school as an organisation. An interesting fact is that students often associate absence of personal qualities necessary to work as teachers with problematic pupils, i.e. students think that they are unable to maintain self-control or have insufficient skills to explain things. As many skills can easily be acquired, the Bachelor's level curricula could include an education course, offering students opportunities to test their abilities in real teaching situations, thus maybe changing their beliefs about self and the direction of career choices. 


\section{Discussion and conclusions}

This study aimed at seeking answers to the following questions: How clear were the students' motives to study the area of natural sciences? How does the clarity of motives relate to students' satisfaction with their studies? How is students' satisfaction with studies related to the interest to continue studies in teacher education? And what are the reasons to choose or not to choose teacher education? As the number of participants was relatively small and concentrated on Bachelor's level undergraduates in the area of natural sciences of only one university, any generalisation to the wider population must be made with caution.

The findings indicate that $23 \%$ of the students were uncertain about why they had chosen to study natural sciences in the university. Of them, $10 \%$ are still not sure whether the choice of curriculum was right. Research shows that majority of students who drop out of higher education do so in their first year (Byrne \& Flood 2005, p. 113). Increasing participation in higher education has brought to university students of various backgrounds, level of readiness and expectations. Unrealistic expectations and unclear goals often lead to dropping out and, therefore, this group of students consists in a risk group who may not graduate. On the other hand, the study indicates that the more informed the students' choice of curriculum is, the greater was their satisfaction with studies. Also, a significant difference appears between students' clarity of reasons and motives in choosing the particular curriculum and interest in continuing studies in teacher education. Therefore, universities preparing teachers must pay much more attention to developing their counseling systems (both curriculum and carrier counseling). Informed and motivated choice of studies ensures satisfaction with the studies and helps to prevent disappointment in later professional life.

It is argued that it is the degree of match between what persons want from a career and the extent to which they think a particular career offers what they want that has a crucial influence on their career decision-making (Kyriacou \& Coulthard, 2000). The view of what is wanted from a career and what teaching is thought to offer will vary from person to person. This study showed that some of the participants had probably already made their decision to take up teacher education by the time of entering the Bachelor's degree studies and for them, the most important reasons were intrinsic in nature. Other researches have also confirmed that the intrinsic value is among the highest rated motivations for choosing a teaching career (Watt \& Richardson, 2007). On the other hand, the findings indicate that the integrated curriculum is better than the $3+2$ system curriculum for students who are already clearly oriented towards teacher education when they first choose the curriculum they wish to study, which parallels the study which shows that non-integrated academic teacher education is a negative predictor of graduates' entrance into the teaching profession (Rots at al. 2007). This may be one of the factors why only $36 \%$ of the respondents expressed the desire to continue in teacher education.

If we want to encourage more graduates to opt for teaching, we also need to explore how teaching is viewed by those who want to choose other careers. Answers provided by the participants indicated that most of the reasons why the respondents thought that a teaching career would not be among their future choices was due to work-related deficiencies (including both material and student-related reasons). Other studies have indicated that improving salary and working conditions are important factors to help 
increase the professional status of the teaching profession (Kyriacou \& Coulthard, 2000). Another important reason why the respondents did not want to choose teacher education was the felt absence of personal qualities necessary for work as teacher. However, the objective of teacher education lies namely in building skills needed for teaching career and therefore students' beliefs about a lack of relevant qualities may be premature. It is essential that some pedagogy courses be included in the Bachelor programme to help create a more realistic understanding of teaching practice and to provide students with opportunities of testing their skills and through this become more certain about their future choices.

Kyriacou and Coulthard (2000) also note that, to improve teacher recruitment, we need to focus on those factors that undergraduates undecided about teaching as a career view as important in influencing their choice of career and to show that teaching will offer a pleasant working environment.

To successfully construct an educational environment that engages the hearts and minds of students, educators need to develop an awareness of, and sensitivity to, their students' motives, preparedness, and expectations. Special attention needs to be paid to the training of teachers to be able to develop the knowledge and skills needed for a sustainable future as well as changes in values, behaviours, and lifestyles. To have teachers in teacher training, academic leaders should, on the one hand, serve as role models to future teachers and, on the other hand, pay much more attention to the counseling system and popularising the teaching profession. It is essential that teacher education attract learners who have the desire and who are ready to work as teachers after they graduate.

\section{References:}

Byrne, M., \& Flood, B. (2005). A study of accounting students' motives, expectations and preparedness for higher education. Journal of Further and Higher Education, 29(2), 111-124.

Entwistle, N., McCune, V., \& Hounsell, J. (2002). Approaches to studying and perceptions of university teaching-learning environments: Concepts, measures and preliminary findings. Enhancing Teaching-Learning Environments in Undergraduate Courses (ETL) Project. Occasional Report 1. University of Edinburgh.

Retrieved June 25, 2007, from http://www.tla.ed.ac.uk/etl/docs/ETLreport1.pdf

Environmental Audit Committee (2003). Learning the Sustainability Lesson. Report. Retrieved April 20, 2009, from http://www.parliament.the-stationery-office.co.uk/ $\mathrm{pa} / \mathrm{cm} 200203 / \mathrm{cmselect} / \mathrm{cmenvaud} / 472 / 47202 . \mathrm{htm}$

Kyriacou, C., \& Coulthard, M. (2000). Undergraduates' views of teaching as a career choice. Journal of Education for Teaching, 26(2), 117-126.

Riigikontrolli aruanne [Report of the National Audit Office]. (2004). Õpetajate puudus üldhariduskoolides. Aruanne [Lack of teachers in comprehensive schools. Report]. (Nr. 2-5/04/14)

Rots, I., Aelterman, A., Vlerick, P., \& Vermeulen, K. (2007). Teacher education, graduates' teaching commitment and entrance into the teaching profession. Teaching and Teacher Education, 23(5), 543-556.

Sterling, S. (2001). Sustainable education. Re-visioning learning and change. Green Books for the Schumacher Society, UK. 
UNESCO. ( 2003). Decade of Education for Sustainable Development. Framework for a draft international implementation scheme. Retrieved April 20, 2009, from http://portal.unesco.org/education/en/ev.php-URL ID=23365\&URL DO= DO TOPIC\&URL SECTION=201.html

Watt, H. M. G., \& Richardson, P.W. (2007). Motivational factors influencing teaching as a career choice: Development and validation of the FIT-choice scale. The Journal of Experimental Education, 75(3), 167-202.

\section{Correspondence:}

Katrin Poom-Valickis, Institute of Educational Sciences, Tallinn University, Narva str 25, Tallinn 10120, Estonia. Email: katrinpv@tlu.ee 